\title{
The Neoclassical Revival in the Architecture \\ of St. Petersburg/Petrograd: \\ Polemic and Practice
}

\author{
William C. Brumfield* \\ Tulane University \\ New Orleans, Louisiana, USA
}

Received 27.12.2016, received in revised form 03.01.2017, accepted 04.02.2017

\begin{abstract}
After 1905 a reaction against the modernist movement in architecture appeared in the work of architects and critics who supported a revival of Neoclassicism in Russian architecture. Although the new classicism provided the means to apply technological and design innovations within an established tectonic system, it was also widely interpreted as a rejection of the unstable values of individualism and the bourgeois ethos. Neoclassical architecture became the last hope for a reconciliation of contemporary architecture with cultural values derived from an idealization of imperial Russian grandeur. Yet the revival of Neoclassicism ultimately manifested the same lack of aesthetic unity and theoretical direction as had the style moderne, thus leading certain critics and architects to question the social order within which architecture functioned in the decades before the 1917 revolution. This debate would have lasting repercussions for Soviet architecture.
\end{abstract}

Keywords: Architecture of St. Petersburg, neoclassical revival, journal Starye Gody, journal Apollon, style moderne, Vienna Secession, Oskar Munts, Fedor Lidval, Ivan Fomin, Carlo Rossi, Vladimir Shchuko, Marian Lialevich, Marian Peretiatkovich, Georgii Lukomskii, apartment buildings, bank buildings.

DOI: 10.17516/1997-1370-0016.

Research area: art history.

The neoclassical revival in Russian architecture, extending from the latter part of the first decade of the 1900s until the revolution, formed part of a larger cultural movement that encompassed both artistic and intellectual life during the decade before the revolution. In the forefront of refined neoclassical aestheticism stood the journal Apollon, which began to appear 1909 under the editorship of the poet and critic Sergei Makovskii. Although primarily a literary journal with a strong interest in the visual arts, Apollon contained frequent commentary supporting the new classicism in architecture, as well as lengthy articles, copiously illustrated, on the neoclassical revival and its ideological significance. In this journal the revived classical form in Russian architecture was praised as an expression of nobility and grandeur that stood in opposition to the questionable (bourgeois) values of the

(c) Siberian Federal University. All rights reserved

* Corresponding author E-mail address: william.brumfield@gmail.com 
style moderne - Russia's equivalent to art nouveau and the Vienna Secession.

One of the most visible examples of the style moderne was the Singer Building (Fig. 1) on Nevskii Prospekt at the Catherine Canal, a combination of moderne and Beaux Arts design with contemporary construction techniques. ${ }^{1}$

There are many ironies in this situation, not the least of which is Apollon's own impeccable «bourgeois» credentials - in terms of its publisher, its writers, and its readership - although perhaps for that very reason, its Parnassian sympathies reacted the more strongly against the bourgeoisie as a cultural phenomenon. Furthermore, the distinction between the retrospective and the modernist components in the neoclassical revival (in Russian, simply neoklassitsizm) is a complex matter, since the revival often represented

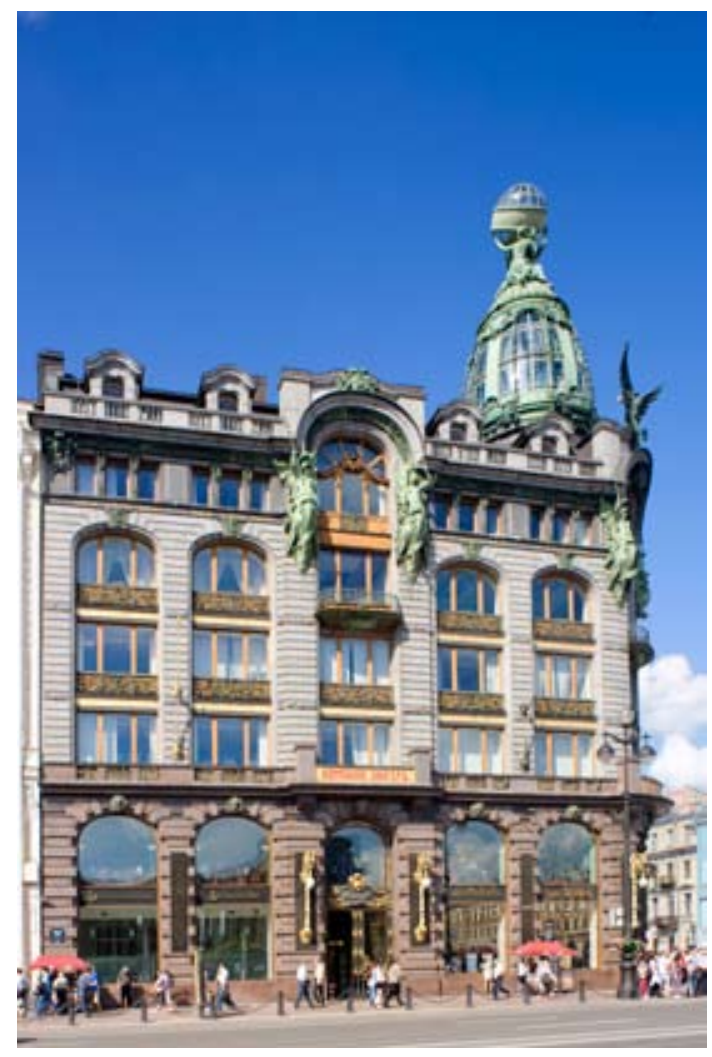

Fig. 1. St. Petersburg. Singer Building, Nevskii Prospekt, No. 28. Photograph: William Brumfield (31/5/2013) little more than an extension of the technical innovations of the moderne with different stylistic markers. Such is particularly the case in the design of large-scale commercial buildings. Architects occupied with the design of neoclassical private houses, by contrast, were to adhere more closely to the verities established in the last great epoch of Russian neoclassicism, the «Empire» style during the 1820 s and 30 s.

It should also be noted that the neoclassical revival flourished in Moscow, ${ }^{2}$ as in Petersburg; yet the former city was more closely identified with the style moderne. In an ideological sense the neoclassical revival was centered in Petersburg, which, as the imperial capital, not only contained the great monuments of an earlier neoclassicism, but also housed the major cultural and architectural journals, whose critics frequently commented on the cultural ramifications of the revival in various new buildings. The following analysis will therefore focus on specific examples of the neoclassical revival as it developed in the architecture of Petersburg from the late 1900s to World War I.

The origins of the neoclassical revival can be traced most clearly in the work of Ivan Fomin (1872-1936). Fomin's career, like that of many of his contemporaries, was peripatetic and influenced by political events. In 1894 he entered the Academy of Arts, in Petersburg, but interrupted his studies in 1896 following a political protest, after which he left for a year in France and returned to Moscow as an architectural assistant. His mentors at the turn of the century included versatile modernists such as Fedor Shekhtel and Lev Kekushev, and Fomin himself made a significant contribution to the new style with his interior designs and project sketches for houses. ${ }^{3}$

Equally important was the influence of Aleksandr Benois, an arbiter of taste and culture who in 1902 published an article entitled «Picturesque Petersburg» in Mir iskusstva. 
Benois resolutely defended the capital's classical architectural heritage at the expense of its new (post-classical) architecture and proclaimed that one must "save [Petersburg] from destruction, stop the barbarous deformation, and preserve its beauty from the encroachments of crude boors who treat the city with such incredible carelessness. $\rangle^{4}$ The implications of Benois's statement were immediately clear to his contemporaries: Petersburg was being destroyed by entrepreneurs whose new buildings violated the spirit of the imperial architectural ensemble. ${ }^{5}$ To those who criticized his attack on modern architecture, Benois responded with another critical essay, «The Beauty of Petersburg,» in Mir iskusstva: «The quest for profit and the reconstruction of buildings is entirely natural, but it is unforgivable when buildings are disfigured in the process. ... Unfortunately our architects . . prefer pathetic parodies in the deutsche Renaissance, in French Rococo, in the gothic (the Faberge building), or more recently - oh horrors! - the absurdly interpreted style moderne.. ${ }^{6}$

In 1903, the year following Benois's articles in Mir iskusstva, Fomin entered a design competition for a country house in the classical style on the estate of Prince P. P. Volkonskii. His entry was a modernized interpretation of classical elements, quite unlike the imitations of the neoclassical manor house during the decade to come, and yet already at the point of abandoning the style moderne. In 1904 Fomin published his own panegyric, also in Mir iskusstva, to the neoclassical architecture of early nineteenthcentury Moscow. The emotionalism of the architect's description is deliberately opposed to what he interprets as the sterility of urban architecture:

The poetry of the past! An echo of the inspired moments of the old masters! Not everyone can understand the subtle feeling of sadness for the faded beauty of the past, which at times is replaced by an involuntary thrill before the grandiose monuments of architecture, Egyptian in their force and combining strength with the delicacy of noble, truly aristocratic forms.

By some strange stylistic act of a trivialized species of people and their talentless artists, multi-storied buildings are already replacing these amazing structures from the epoch of Catherine II and Alexander I. There remain so few of them. All the more valuable are they. All the more do I love them. ${ }^{\text {? }}$

In the fall of 1905 Fomin returned to the Academy of Arts, where he was accepted for advanced study in the architectural studio of Leontii Benois, and remained there until his graduation in the spring of 1909 , by which time he had irrevocably moved toward the neoclassical revival. His allegiance was reflected not only in project sketches drawn with exceptional brilliance, but also in scholarly and archival work involved in an exhibition of eighteenth-century Russian art and architecture.

Although the Historical Exhibition of Architecture, originally scheduled for 1908 at the Academy of Arts, did not open until 1911, Fomin published a statement in 1908 of the exhibit's purposes in what had become his preferred journal, Starye gody (Bygone Years). It is particularly interesting to observe not only his confidence in the historical mission of the exhibit in overcoming the neglect of post-Petrine architecture, but also his polemical argument that modern architecture lacked some essential force present in the neoclassical period: «In our time, on the contrary, everyone scurries about trying to be individual, everyone wants to invent «his own,» to do things deliberately not like others; and as a result, not only is there no reigning style, but one does not see even those guides who would in the future stand at the head of a general cause 
deserving, at last, to be expressed in the guise of the new. $\rangle^{8}$

The critical reappraisal of neoclassicism had by 1911 achieved general acceptance, in no small part through the efforts of Fomin, whose work now included a number of neoclassical revival houses in a refined manner unsurpassed by any of his contemporaries. ${ }^{9}$ However, it was in the area of large-scale development - and not in the design of private houses - that the neoclassical revival had ultimately to justify itself as an alternative to the moderne in the shaping of the urban environment. Fomin's contribution to this development will be discussed below; but an earlier example of the evolution from the moderne to modernized classicism can be found in the work of the Petersburg architect Fedor Lidval (1870-1945), who built two banks in the latter style between 1907-09: the Azov-Don Bank (Fig. 2,3) and the Second Mutual Credit Society

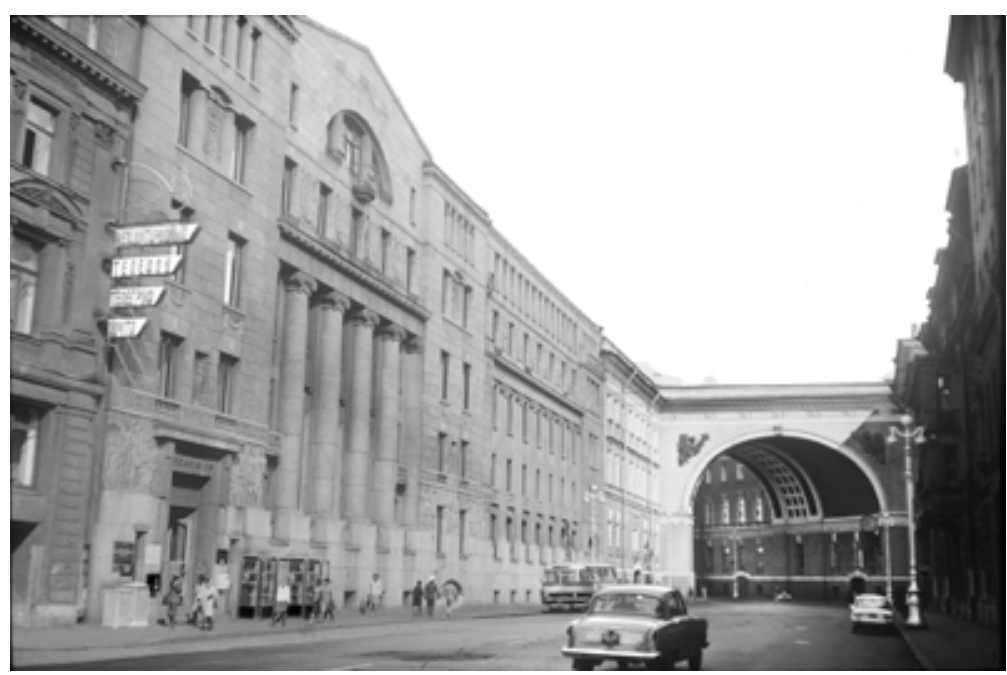

Fig. 2. St. Petersburg. Azov-Don Bank, Bol'shaia Morskaia Street. In background: Arch of the General Staff Building. Photograph: William Brumfield (9/1971)

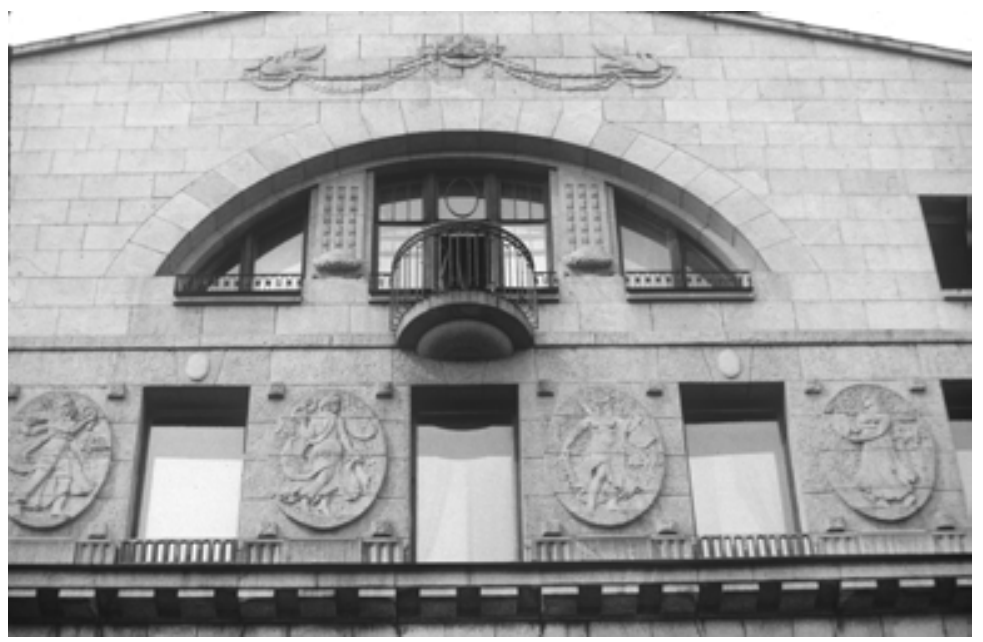

Fig. 3. Azov-Don Bank, Bol'shaia Morskaia Street. Façade detail. Photograph: William Brumfield (3/8/1991) 
(Fig. 4, 5, 6). ${ }^{10}$ Both exploit the texture and color of granite, as well as the sculptural qualities of natural stone in the decoration of the facade. And both made extensive use of iron structural components on the interior to support the spacious transaction halls and adjoining office space. With these two buildings Lidval defined a new style of commercial architecture that applied modern technical methods of construction with references to classical architectonics. This reference was particularly apposite for the Azov-Don Bank, located at the beginning of Bolshaia Morskaia Street with Carlo Rossi's magnificent Arch of the General Staff Building as an originating point
The social and aesthetic implications of this use of classical elements for a modern commercial structure were quickly grasped in the first issue of Apollon by Georgii Lukomskii, who noted that the new classical style had entered the service of an empire of commerce: "This building [the Azov-Don Bank] has none of the «nobility» of our Empire structures; but then the goal of a bank - to convey the expression of a palace of the bourgeois type - excludes it.»" Despite the lack of «noble perfection» in Lidval's adaptation of neoclassical elements, Lukomskii saw in his work enormous possibilities: «In general the buildings of Lidval approach those types that, in all likelihood, are fated to resolve the difficult question concerning

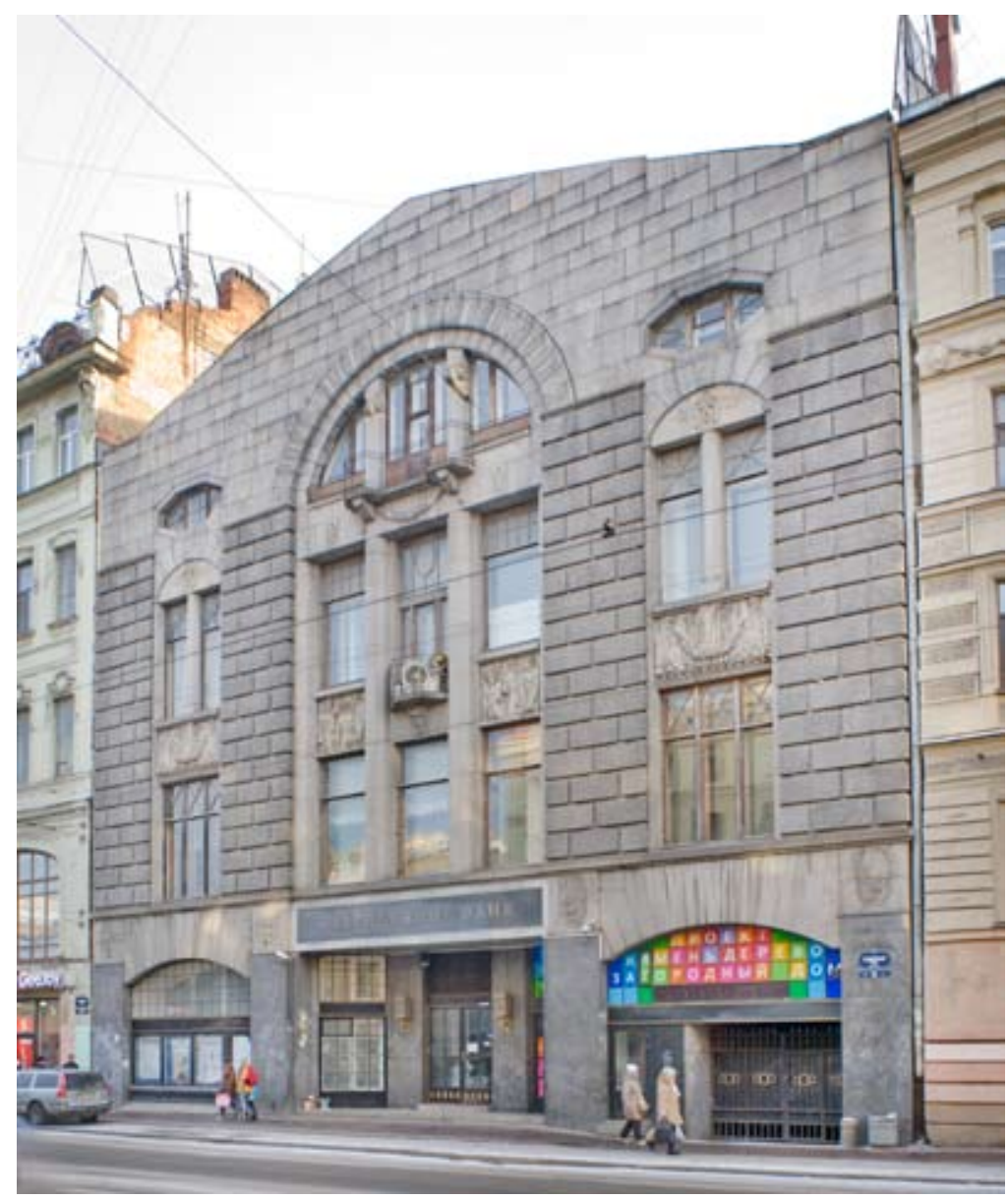

Fig. 4. St. Petersburg. Second Mutual Credit Society Building, Sadovaia Street, No. 34. Photograph: William Brumfield (2/1/2017) 


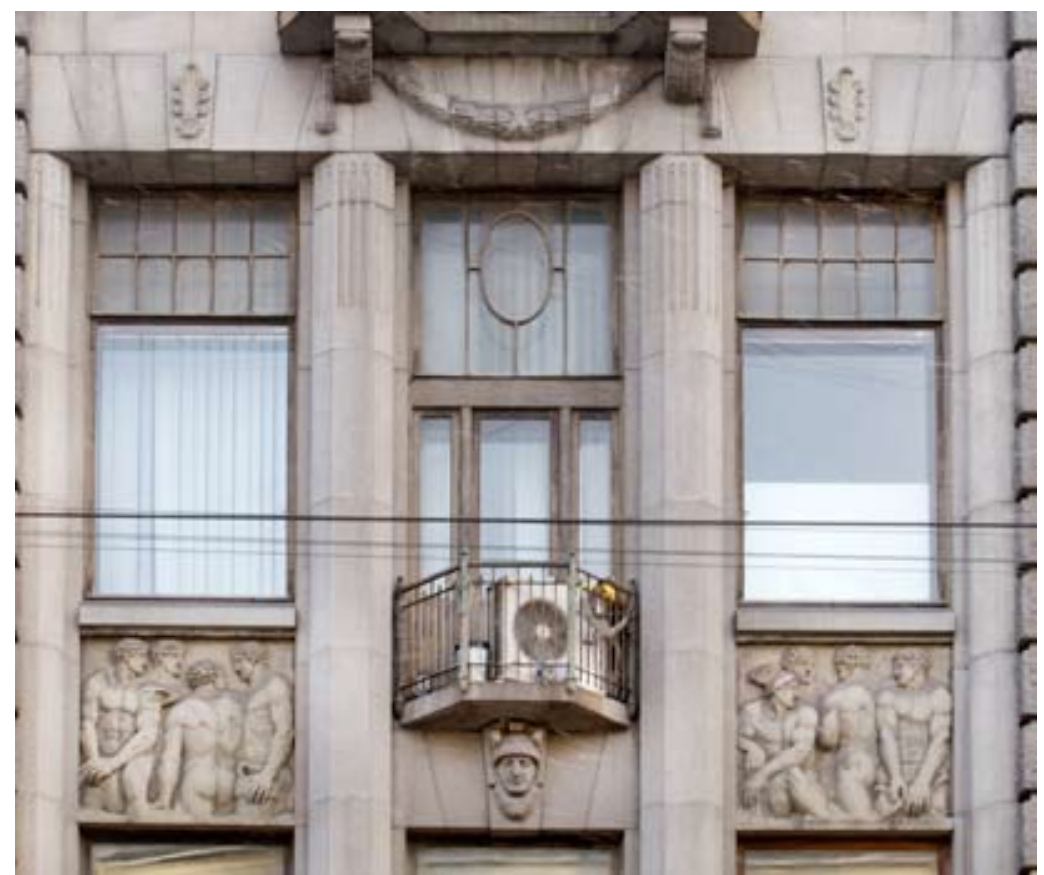

Fig. 5. Second Mutual Credit Society Building. Façade center with sculpted panels. Photograph: William Brumfield (2/1/2017)

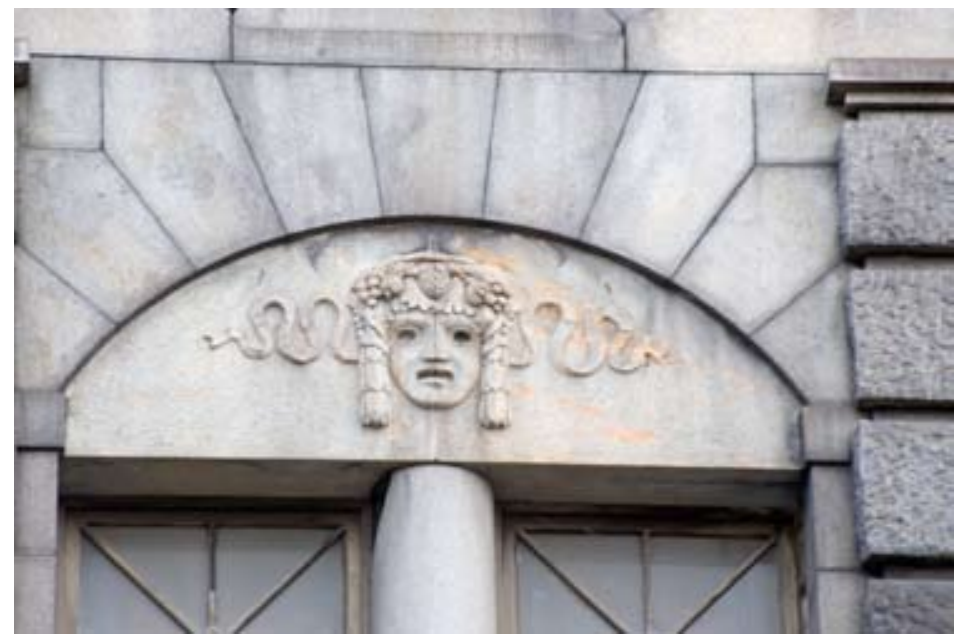

Fig. 6. Second Mutual Credit Society Building. Window pediment, decorative detail. Photograph: William Brumfield (2/1/2017)

the harmony of the «new» construction with the established principles and traditions of historical architecture in St. Petersburg.»

The attention given Lidval's work in the first issue of Apollon is an event of much significance in the propagation of the neoclassical revival; for Lidval had established that essential connection between neoclassicism and modern, «bourgeois» architecture by melding a functional commercial structure and an aesthetic system derived from 
monumental architecture of St. Petersburg. Another neoclassicist, Marian Peretiatkovich, turned to the Italian Renaissance, which he had studied as a pupil of Leontii Benois at the Academy of Fine Arts and seen during his diploma trip to Italy in $1906 .{ }^{12}$ His design for the Vavelberg Building (containing the Petersburg Trade Bank) at the beginning of Nevskii Prospekt, combined features of the Florentine quattrocento, such as the rusticated stone work of Michelozzo's Palazzo Medici, with the double arcade of the Palace of Doges in Venice (Fig. 7). On a narrower facade, Peretiatkovich repeated the style of the Renaissance palazzo in his design for the Russian Bank of Trade and Industry (1912-14), which incorporated elements of 16th-century Italian palaces.

The neoclassical revival appeared in other types of commercial architecture, such as large retail stores, where the fashion for classical detail coexisted with an expression of modern structure and construction technology. A particularly successful example is Marian Lialevich's building for the firm of F. Mertens (1911-12) on
Nevskii Prospekt. ${ }^{13}$ (Fig. 8) Lialevich began his career with the style moderne, and continued to defend aesthetic freedom that it had brought to architecture. In his most significant publication Lialevich interpreted the evolution of architecture as primarily a social phenomenon, rather than one determined by technology:

In linking the appearance of architectural forms with the qualities of steel and concrete, it seems that we so restrain our concept of the development of architecture as an art, that we repeat the same mistakes that we attribute to architect-theoreticians of the XIX century (Semper, Schinkel). ... Therefore it is not from a familiarity with the properties of «steel and concrete» that a «genuine style» will appear, but from more deeply based elements, from the strivings and ideals of society in the broadest sense [obshchestvennost' ${ }^{14}{ }^{14}$

In this context Lialevich justified the style moderne as a «historical necessity,» whose most important contribution was its sense of freedom from academic restrictions. Fomin and Lukomskii, on

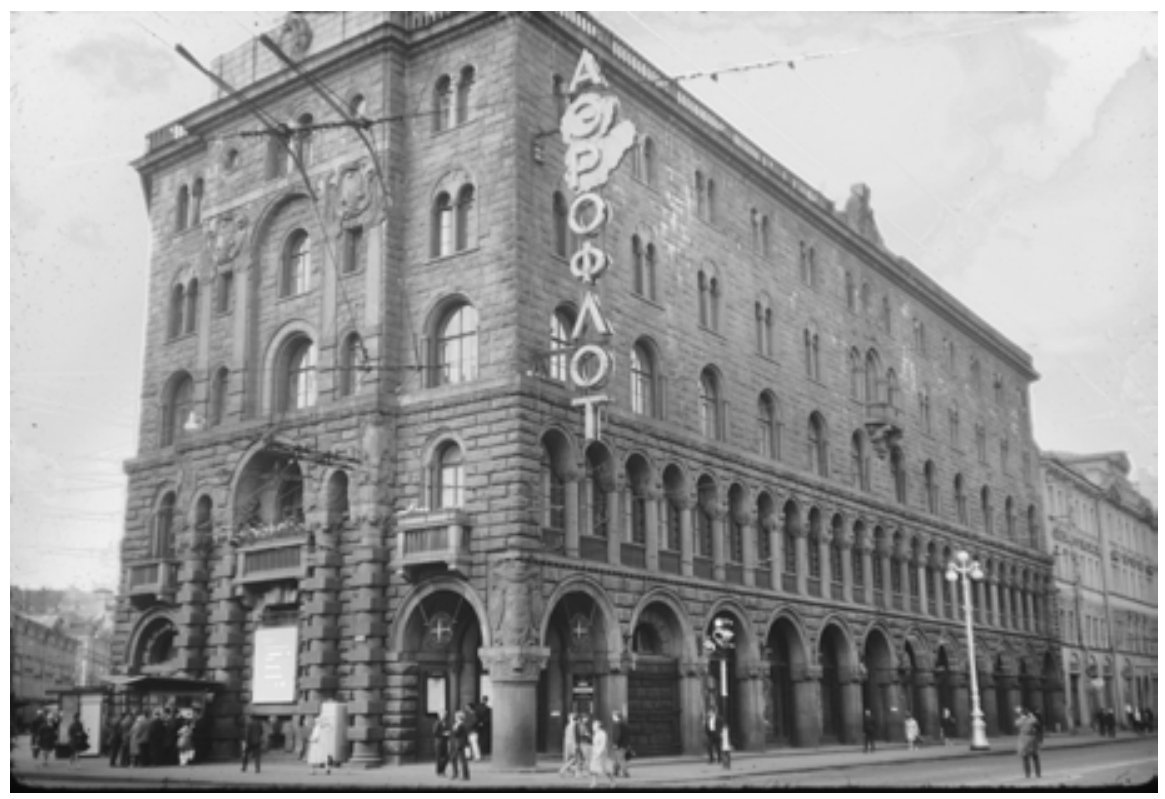

Fig. 7. St. Petersburg. Vavelberg Building, Nevskii Prospekt. Photograph: William Brumfield (9/1971) 


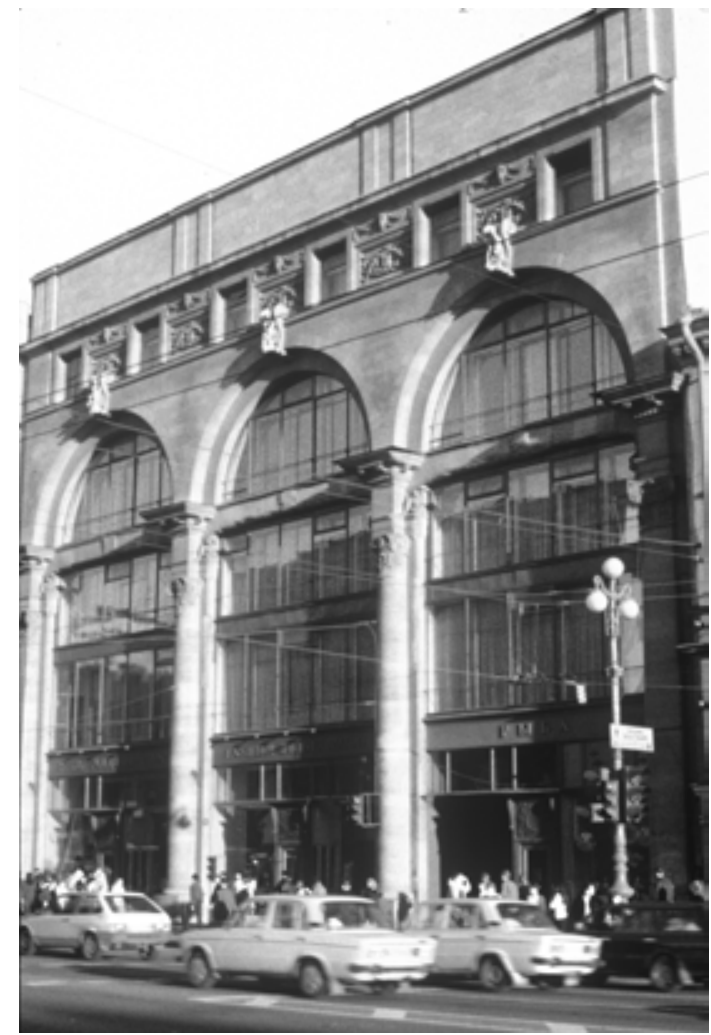

Fig. 8. St. Petersburg. F. Mertens Building, Nevskii Prospekt. Photograph: William Brumfield (29/5/1997)

the other hand, praised the neoclassical revival precisely for its normative aesthetic principles that could be universally applied.

Indeed, the viability of the new classicism was to be demonstrated in the urban bourgeois setting that proponents of the style moderne had claimed as their own. The most ambitious attempt to apply classical elements on a scale commensurate with modern city planning occurred on Golodai Island, an undeveloped area just to the north of Vasilevskii Island in the northwest part of the city. In view of the Russian interest in English concepts of town planning, it is revealing that in 1911 an English investment firm initiated a project, called «New Petersburg,» for a community occupying much of the western part of the island (about one square kilometer). ${ }^{15}$
The general design for the project was entrusted to Fomin, who intended to create a monumental housing development for the city's middle class, thus anticipating the classical aesthetic applied to urban planning in Soviet architecture of the 1930s and 40s, as well as in certain post-modernist developments of middle-class monumentality in the West. Yet very little of the New Petersburg project ever materialized. In 1912 he undertook the construction of one of the five-story apartment blocks, whose «Roman» facades were to follow the curve of the semi-circular entrance park. Financial reasons, exacerbated by the onset of the First World War, halted construction after the two initial stages of the project. For Lukomskii the New Petersburg project gave hope for the creation of a «part of the city with a truly European appearance and a strict unity of classical architectural ensembles, situated

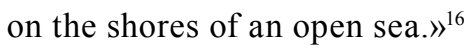

Despite the failure of «New Petersburg,» construction along Kamennoostrovskii Prospekt on the fashionable Petersburg Side (a district to the north of the city center, beyond the Neva) flourished as it had since the beginning of the century, when the tramline appeared and Lidval completed his first major apartment complex in the style moderne. There was no comprehensive plan of development, yet the buildings on the Prospekt and some of its intersecting streets projected a sense of prosperity unique to contemporary Petersburg; and almost all of them adhered to one of the varieties of the neoclassical revival. Foremost in this development was Vladimir Shchuko (1878-1939), who graduated from the Academy of Arts in 1904 and, like Fomin, was awarded a diploma trip to Italy. The early careers of the two architects contain significant parallels: the effect of Italian architecture on their work, and their appreciation for the varieties of Russian neoclassicism, so brilliantly reinterpreted in 
Shchuko's pavilions for the 1911 Rome and Turin exhibitions. ${ }^{17}$

Shchuko's first apartment house on Kamennoostrovskii Prospekt, No. 63 (190810), was constructed for Konstantin Markov, a military engineer and real estate developer who had done the initial structural design. The building, whose fifth story is situated above the profiled cornice, represents a variation on the Italian Renaissance style, with loggias, ionic pilasters, and carved ornamental panels. Yet the Markov apartment house at No. 63 is by no means a simple stylization, for it represents a combination of classical elements within a new concept of monumentality that is distinct from both historicism and modernism.

Shchuko's distinctive resolution of the question of an appropriate style for contemporary urban architecture provided material evidence for the return of classical values propagated by Lukomskii, who devoted much attention to Shchuko's work in a 1914 survey of the neoclassical revival in Apollon: «The buildings designed by the architect V. A. Shchuko (Kamennoostrovskii Pr., Nos. 63-65), were the first classical structures in the new sense of that word; and indeed, not only their general forms but their details were borrowed from the originals and applied to the new conditions of the apartment house. In addition, implementation is itself beginning to play an enormous role: the important thing is not only how to design a project, but also how to work out the details. .... ${ }^{18}$

His subsequent, and adjacent, apartment house for Markov (No. 65; built in 1910-11) adopted a more forceful display in its massive articulation of the classical order (Fig. 9, 10, 11). The attached composite columns rise four floors, from the top of the ground floor to the attic floor, which is itself designed in the form of a colossal broken cornice. The shafts of projecting window bays are wedged between the columns that define the main part of the facade in a slender balance between practicality and pomposity. Despite his praise for the loggias and the subtlety in detail of Shchuko's first building, Lukomskii was even

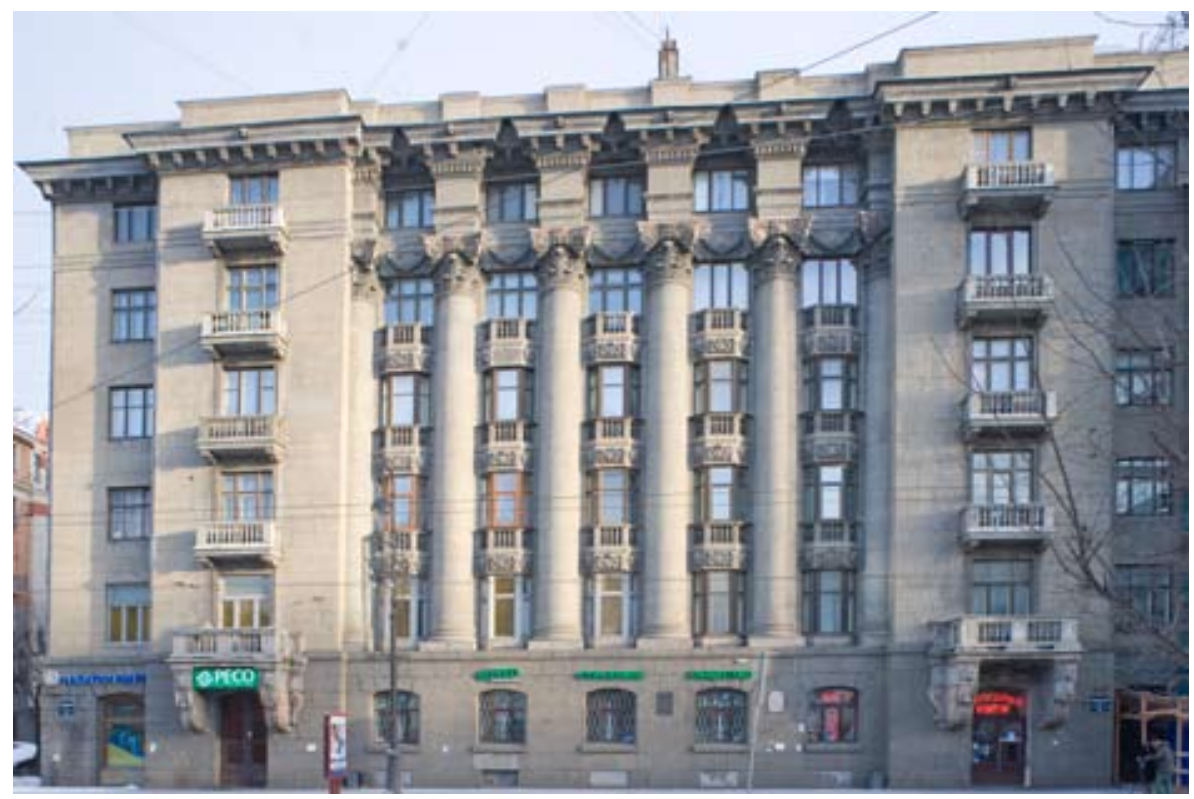

Fig. 9. St. Petersburg. Konstantin Markov apartment building, Kamennoostrovskii Prospekt, No. 65. Main façade. Photograph: William Brumfield (2/1/2017) 


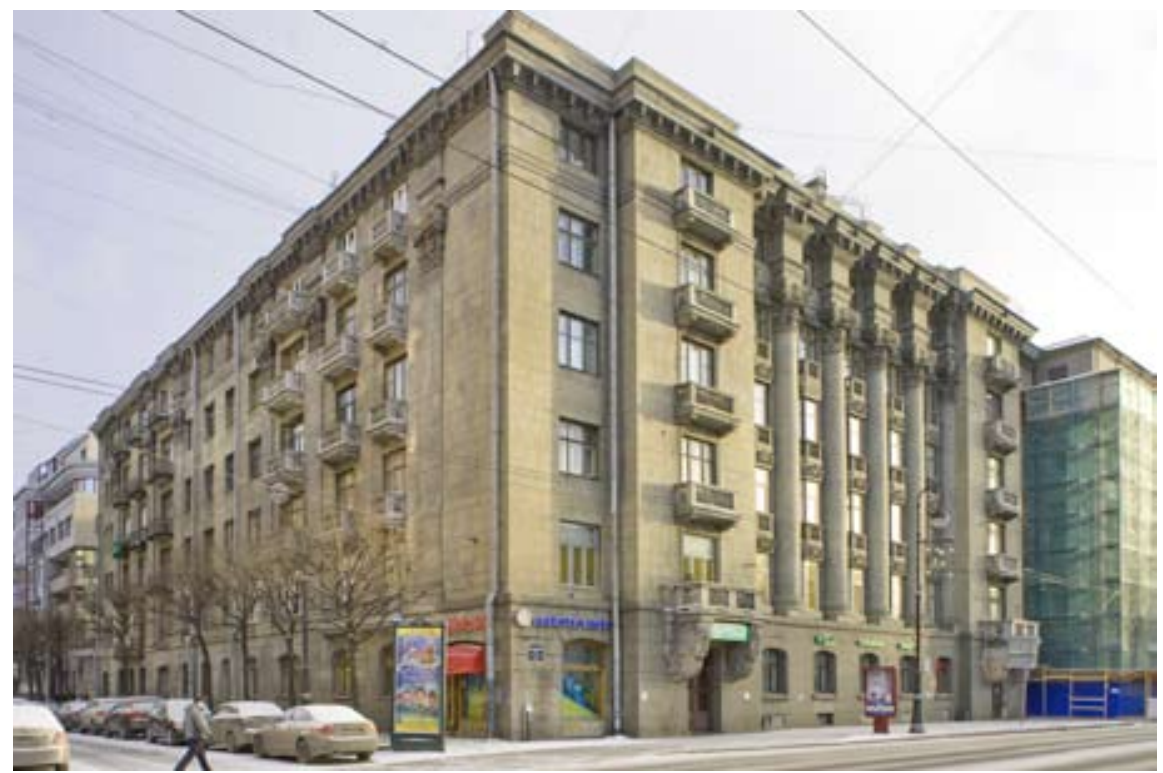

Fig. 10. Konstantin Markov apartment building, Kamennoostrovskii Prospekt, No. 65. General view with Graftio Lane. Photograph: William Brumfield (2/1/2017)

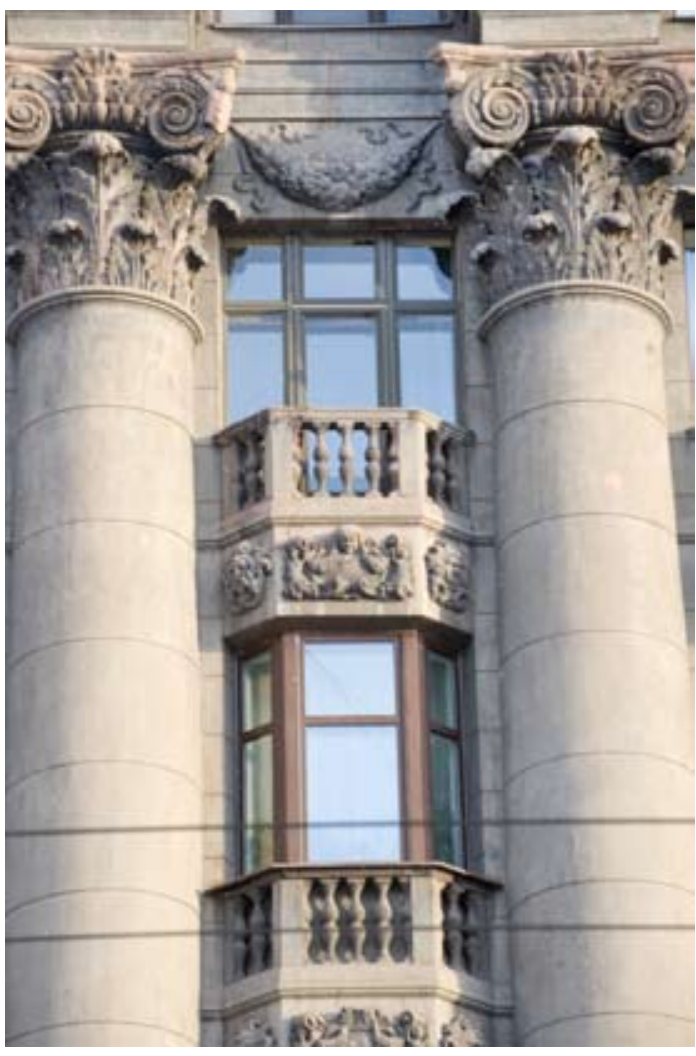

Fig. 11. Konstantin Markov apartment building, Kamennoostrovskii Prospekt, No. 65. Main façade, window bay. Photograph: William Brumfield $(2 / 1 / 2017)$ more impressed by the hypertrophied forms of the second, which proved that the classical system of orders could be applied on a scale commensurate with the demands of a modern city. ${ }^{19}$

At the Fourth Congress of Russian Architects, held in Petersburg in January 1911, Lukomskii gave the most concentrated expression of his advocacy of the neoclassical revival as the proper style of the times. Having dismissed the style moderne as a rootless invention of «a little decade-long epoch of individualism,» the critic noted with relief the return to principles in architecture: «Having endured an epoch of agitated searching for a new form, new beauty and ornamentation, and having been convinced of the impossibility of bright achievements without correspondingly new constructive devices and materials, architecture - like art - became ashamed of its irrationality, and is again joyously repeating and taking as its base the old national forms, while waiting for the decisive discoveries of an iron architecture that has not yet found its superb form. $\rangle^{20}$ In his survey of the neoclassical revival, Lukomskii found much to criticize in the 
facile applications of Empire motifs («pastrycake Empire»), but approved of the turn to the «stern taste of Italian [Renaissance] architects» on the part of Shchuko, Lialevich, Lidval, and other Petersburg architects.

Yet the very cult of individualism that both Fomin and Lukomskii had criticized in their commentary on the demise of the style moderne now flourished within the varieties of the neoclassical revival - whether in St. Petersburg or in Moscow, where Roman Klein, Ivan Zholtovskii and others had established a vigorous neoclassical movement. Whatever the ideological implications in the transition from the style moderne to the classical model, the economic, entrepreneurial basis of apartment construction remained the same - as in evident in the two idiosyncratic

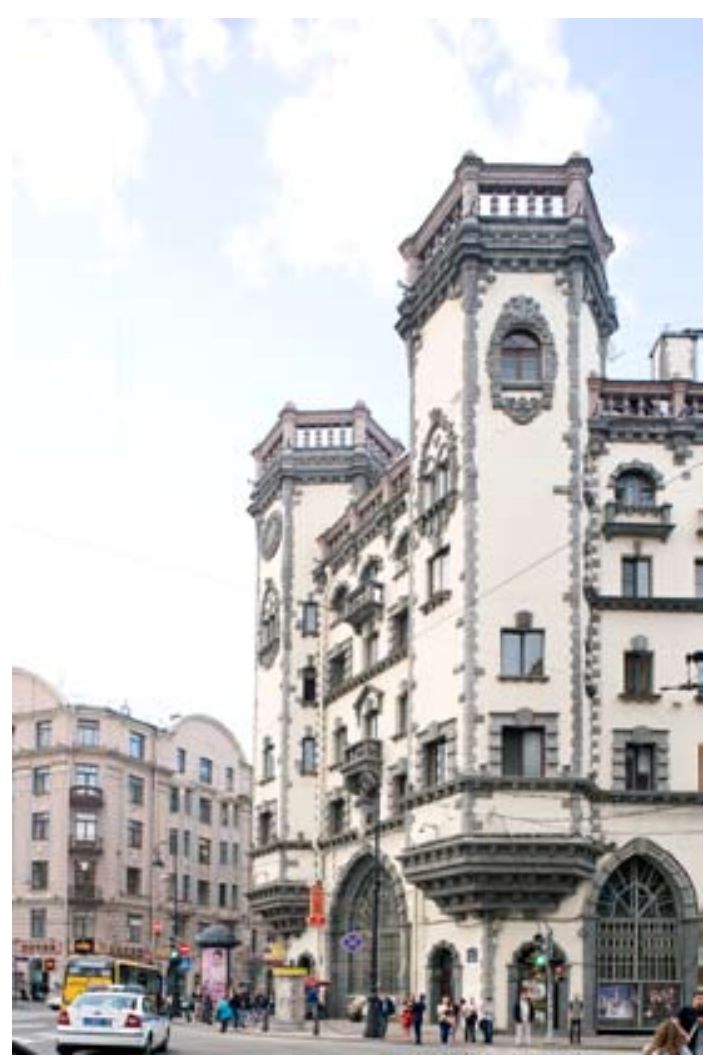

Fig. 12. St. Petersburg. K. I. Rozenshtein apartment building, Kamennoostrovskii Prospekt, No. 35 \& Bol'shoi Prospekt, No. 75. Main façade. Photograph: William Brumfield (30/5/2013)
Italianate apartment houses that Andrei Belogrud built between 1912 and 1915 on the Petersburg Side with the participation of the engineer and developer Konstantin Rozenshtein.

The first of these apartment buildings was erected at the prominent intersection of Kamennoostrovskii Prospekt No. 35 and Bolshoi ProspektNo.75(Fig. 12,13). It applied Renaissance and Italian Gothic motifs in a manner that could be characterized as post-modernist avant la lettre. The second, at Bolshoi Prospekt No. 77 can be seen as a variation on Shchuko's second Markov building, but in a more concentrated form (Fig. 14). The façade is dominated by colossal attached composite columns with flat square windows between them. Above the sixth floor a large broken cornice with massive dentils

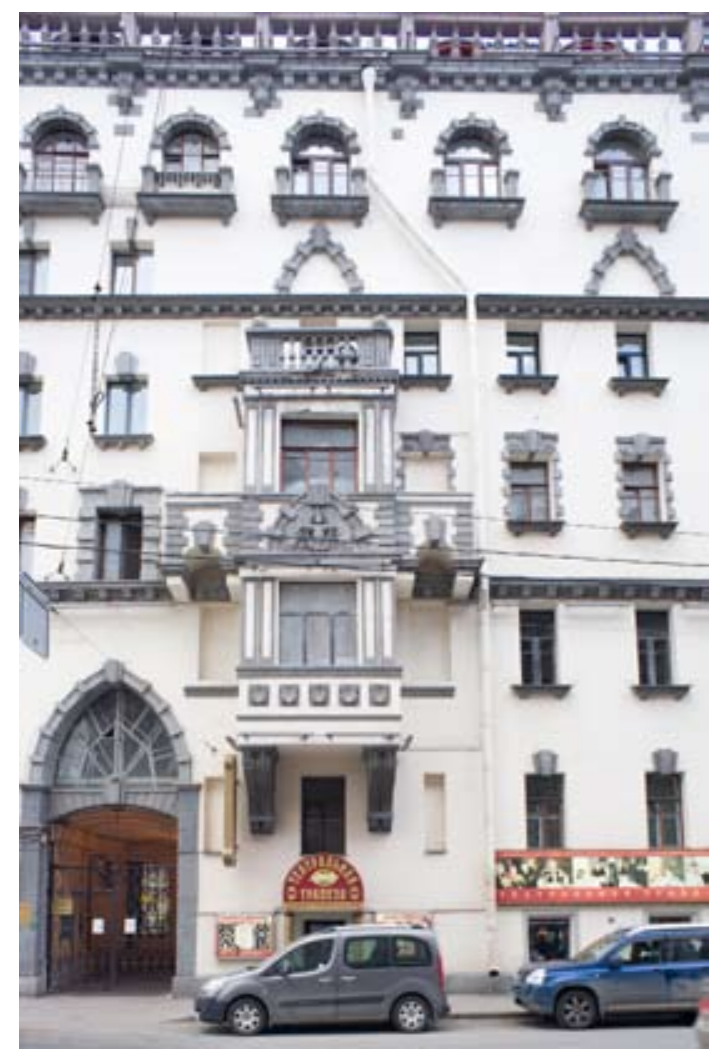

Fig. 13. K. I. Rozenshtein apartment building, Kamennoostrovskii Prospekt, No. 35. Façade on Lev Tol'stoi Street, No. 2. Photograph: William Brumfield (30/5/2013) 


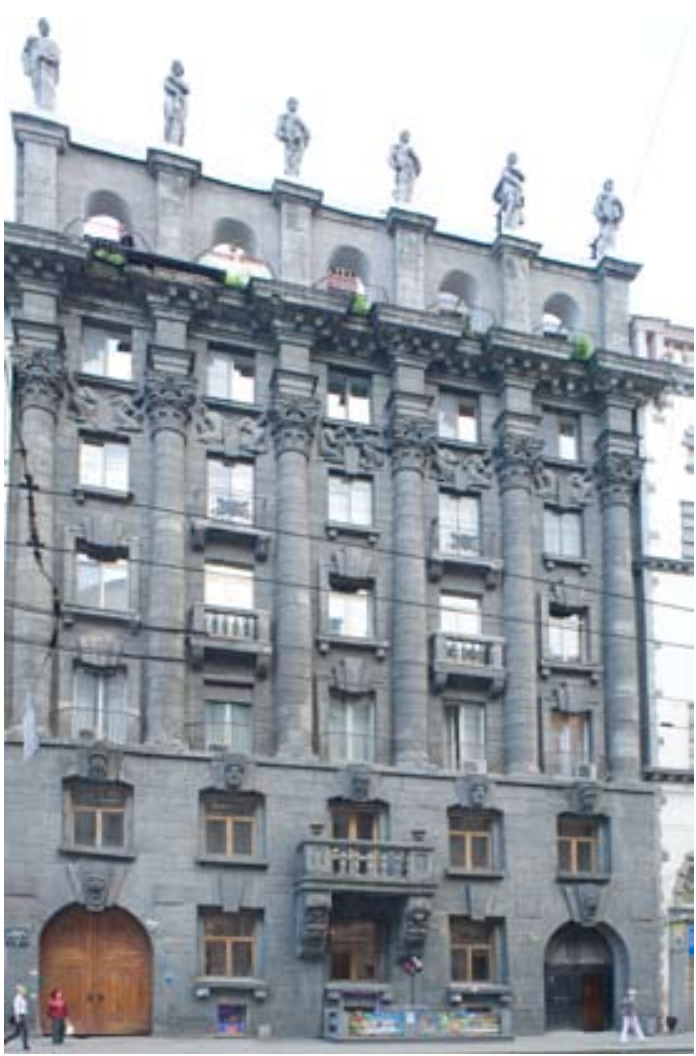

Fig. 14. St. Petersburg. K. I. Rozenshtein apartment building, Kamennoostrovskii Prospekt, No. 35 \& Bol'shoi Prospekt, No. 77. Photograph: William Brumfield (30/5/2013)

projects over the column shafts, but this is not the culmination. Above is yet another cornice with six classical statues. Designers of Renaissanceinspired and neoclassical revival buildings, no less than those of the moderne, used stylistic identity as an advertisement for the amenities that justified the cost of living at a fashionable address.

In praising the return to classical monumentality for modern urban housing (particularly on the scale of New Petersburg) Lukomskii was imposing an architectural ideal from the pre-capitalist era within an environment created by and for private financial interests. Indeed, he did so quite consciously, as is evident in the comments on Fomin from his 1913 survey of contemporary neoclassical architecture in Apollon:
«The beauty of Fomin's work is unquestioned and is so close to all that which resides at the very basis of Old Petersburg; thus it is unforgivable not to make use of this master! Moreover, Fomin's art does not at all correspond to the contemporary economic spirit of calculation and triviality, of contemporary cheapness and bad workmanship; and this, of course, makes it difficult for him to work on the construction of apartment houses. $)^{21}$

In the preceding attack on the «contemporary economic spirit,» Lukomskii failed to notice that the triviality and cheapness of modern construction (as he saw it) could not have derived from the omnipotence of the bourgeoisie, which was still in its nascent stages of development. Nor could the inability to achieve a coherent modern urban environment be resolved by resorting to an imagined social and economic structure. Indeed, Fomin's most refined work in the neoclassical revival was on the smaller scale of the private residence, albeit for very wealthy patrons. The most notable example is his mansion built in 1913-15 for Prince Semion Abamalek-Lazarev on Moika Quay No. 23 (Fig. 15, 16).

This critique of the neoclassical revival was made most forcefully in 1914 in two related articles on the social aspect of contemporary architecture by the critic V. Machinskii. In the opening remarks to his second article, Machinskii attacked not only the changing fashions of individualism in the arts, but also the sterile imitation of historical styles. From the perspective of social change, Machinsky ascribed the decline of aesthetic sensibility to the loss of cultural hegemony on the part of the nobility, which was succeeded by a number of competing social groups engaged in a process of «mutual struggle and self-definition.» Even the triumph of the bourgeoisie in developed Western countries would prove ephemeral before the rise of the working class. ${ }^{22}$ 


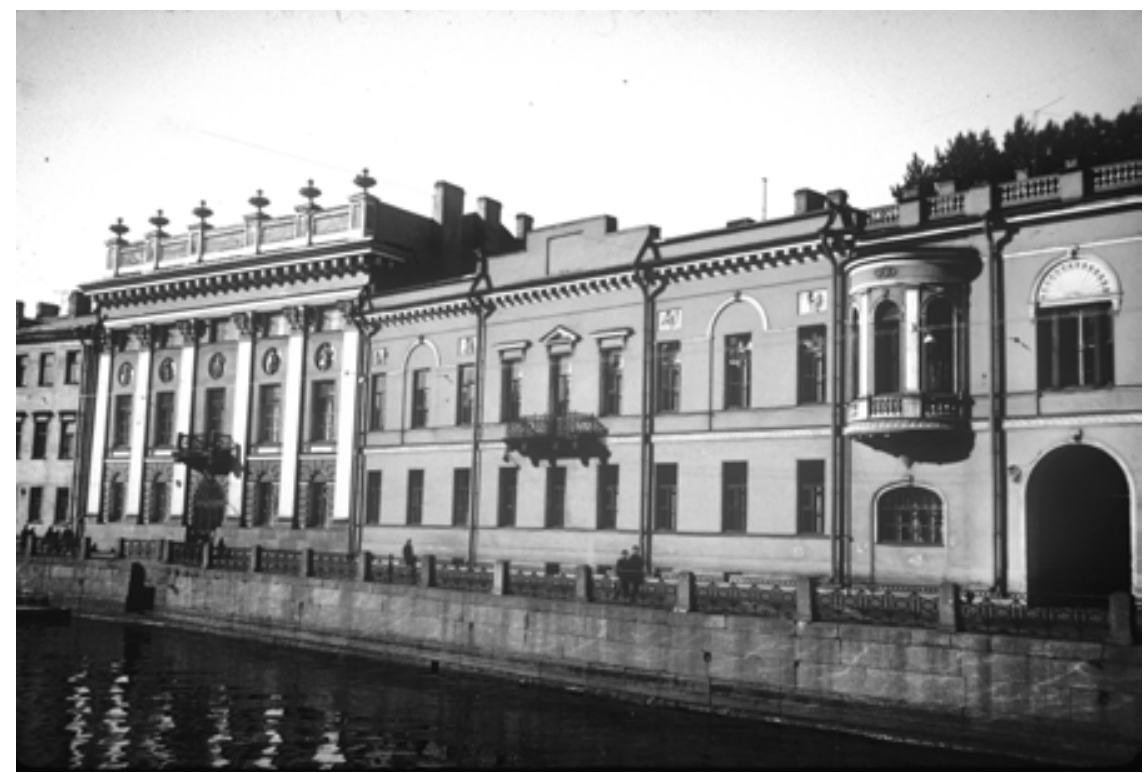

Fig. 15. St. Petersburg. Abamalek-Lazarev mansion, Moika Quay, No. 23. Photograph: William Brumfield (10/1971)

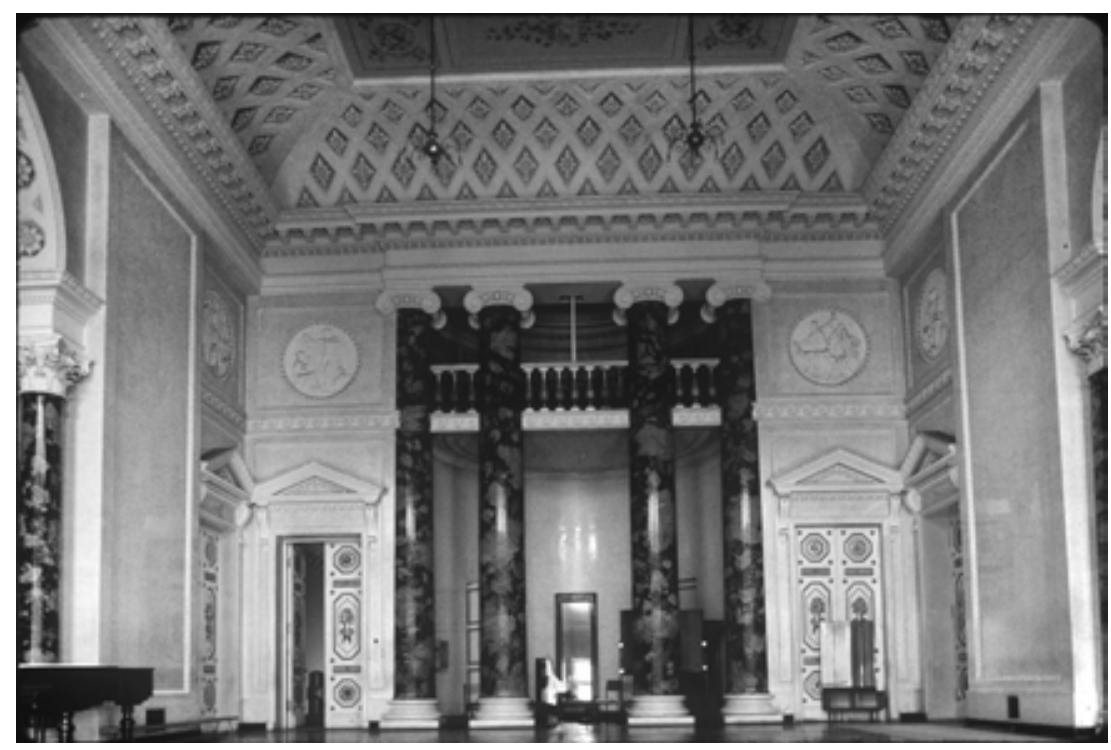

Fig. 16. Abamalek-Lazarev mansion, Moika Quay, No. 23. Interior, banquet hall. Photograph: William Brumfield $(22 / 5 / 1990)$

Although Machinskii greatly oversimplified the issue of class struggle in the West, his perception of the weakness of the Russian bourgeoisie is more to the point. Despite cultural contributions from «individuals, families, and narrow circles» within the bourgeoisie, the class as a whole could not guide society:
[B]y the time this class [the bourgeoisie] comes into maturity, its enemies will also have grown up. That is why contemporary art vainly thrashes about in its searchings, impotent to offer anything other than superficial, mechanical changes. For the time being it has no place from which to take 
a new, substantive view of the world, of new realities, of goals, needs, and tastes that are not forced, since as of yet there is no new, special basis for creativity.

Obviously, this can appear only at the end of the social struggle underway, as a result of the newly-formed social entities. At present there can only be intimations of future needs and tastes, in as much as the classes moving toward dominance in the future exist, take their form, and grow in the present. ${ }^{23}$

Whatever the determinism of Machinskii's sociopolitical interpretation, his analysis not only expressed the quest for a new social and cultural order - as had both Lukomskii and the style moderne critics, in their very different ways - but also saw its incipient presence in an unavoidable class struggle.

Even as the neoclassical revival achieved what seemed to be complete ascendancy over modernism, there were signs that the debate had lost its relevance as the existing social and economic order moved more deeply into crisis. In January 1916 the architect Oskar Munts (1871-1942) published an essay entitled «The Parthenon or Hagia Sophia,» which appeared in response to yet another article by Aleksandr Benois in praise of neoclassicism. ${ }^{24}$ Munts, who incorporated both the modern and neoclassical styles, had received a thorough grounding in classical architecture during his study at the Academy of Arts, from which he graduated in 1896 with the gold medal.

Munts's work as an architect reflected a pragmatic alliance between construction logic and a subdued form of the style moderne in its last phase - although he also submitted a neoclassical design in 1913 for the reconstruction of the Tuchkov Buian (a late eighteenth-century hemp warehouse constructed opposite Petersburg's Vasilevskii Island by Antonio Rinaldi). ${ }^{25}$
For his article he chose the two great monuments of Greek civilization to represent opposite principles in architecture: the Parthenon, a statement in pure form, perfect in detail and unmitigated by utilitarian demands; and Hagia Sophia, imperfect in detail and the ultimate expression of the purposeful, utilitarian logic of construction. Despite the creative adaptations of ancient classicism by the Romans and their Renaissance successors, the only possible choice for the modern age is the constructive principle symbolized by Hagia Sophia. Having reviewed the familiar explanations for the neoclassical revival - as a reaction against the «unceremonious moderne,» and a reflection of the creative stagnation of the age - Munts rejected the application of a supposedly eternal stylistic system to modern structures:

It is both significant and horrible that this neoclassicism, just as much as the infatuation with free decorative forms [the moderne] threatens a general catastrophe: the complete separation of so-called artistic architecture from construction itself, with its technical, engineering innovations. ... In order to avoid the catastrophe, it is necessary to return architecture to its eternal source to purposeful, intelligent construction, the principle of which is so imposingly expressed in the temple of Hagia Sophia. ${ }^{26}$

Munts's article gave rise to an extended polemic with a group of neoclassical revivalists - writing under the name of Duodecim, or the Twelve, and including Lukomskii - who praised classicism as a universal language of architecture and culture. Their lead article, entitled «For Architecture,» accused Munts of too restrictive an interpretation of classicism, and attacked his claim that it ignored the utilitarian, functional nature of structure. ${ }^{27}$ The charges are familiar: not only did an attack on classicism ignore its origins in functional tectonics, but it also reduced the art of 
building to the level of construction technique. Indeed, the same debate had occurred earlier in the century in Russian architectural publications, which in turn reflected the broader European debate - represented by the opposing views in the writings of Otto Wagner and Camille Sitte, or those of Gottfried Semper and Karl Riegl - on the relation between function and aesthetics.

On the eve of revolution, proponents of a new, rational era in architecture (among whom were Machinskii and Munts) dismissed both the moderne and the neoclassical revival, while Lukomskii and Lialevich wrote of their belief in the eventual coming of a new era, but remained convinced advocates of classical tectonics. For Lukomskii, in particular, architecture's mission was to restrain the future and its attendant chaos in favor of aesthetic principles representative of the moral strength of a great people.

There could be no clearer statement of this position than the introduction to Lukomskii's 1913 article «New Petersburg.» Taking a militant monarchist position in the year of the Romanov tercentenary, the critic insisted that great architecture must derive from the power of the state and church:

«Therefore, all efforts to present a «New Petersburg» only on the basis of proposed conditions in economy and hygiene can lead to nothing other than pale, gray facades. For just this reason, the entire epoch of bourgeois and democratic modernism has given Petersburg nothing. Only the restoration of previous architectural canons can increase the beauty of our city. ... A completely ideal [solution] is unthinkable. We do not have the conditions to create it. It is necessary to limit ourselves to retrospectivism. ${ }^{28}$

Although Lukomskii's purposes differed from those of Machinskii, the openly anti-democratic sentiments of the above passage reveal a persistent lack of faith in the viability of the bourgeoisie as a source of governance - social, political, or cultural. Whether these critics advocated a rationalist or a retrospective antidote to the perceived architectural disharmony, each faction demonstrated its readiness to accept a radical, hegemonic solution.

Yet Lukomskii's trenchant polemics stood in fundamental contradiction to the essence of neoclassical aesthetics, whether derived from Renaissance Italy or Alexandrine Petersburg. The sense of order and immutability inherent in the best work of the Russian neoclassical revival beyond politics and effortlessly accepted as the embodiment of truth and beauty - could hardly have existed within the bruising confrontation of social polemics. In essence the uncompromising intellectual debates derived from a presentiment, acknowledged or not, of the certain dissolution of the old order and, in Lukomskii's case, a refusal to accept the current alternatives.

The ultimate ramifications of this train of thought can be found in Lukomskii's book Sovremennyi Petrograd (Contemporary Petrograd), published a few months before the first, so-called «bourgeois,» revolution in February 1917:

It is more and more evident that contemporary Petrograd is losing its national, noble character; is becoming more and more trivial, European. Only a common, amicable effort in matters of construction, only an artistic dictatorship in the distribution of building sites and the attraction of the best resources will save the capital and give it an even more powerful and beautiful appearance than it had during its best days in the epoch of Alexander I. ${ }^{29}$

Not only had Lukomskii turned against the very European ideal (irredeemably bourgeois) that he had so fervently advocated in his earlier comments on «New Petersburg,» but the normative tendency in his writings on neoclassicism had also reached a logical extreme in the reference 
to an «artistic dictatorship.» On one level it is evident that he had in mind what might be called a «planning czar» in city development; yet there is also the telling choice of a term derived from frustration with an inept government whose policies had led to military disasters on the eastern front and a loss of direction at home. The nostalgic reference to Petersburg during the golden age of Alexander I, a century earlier, represented an attempt to revive the glorious myth of the imperial capital and of Russia itself. The collapse of the empire did indeed bring about a dictatorship, ostensibly of the proletariat, although not one immediately concerned with aesthetic or planning issues. Under these circumstances and in view of his monarchist convictions, Lukomskii found it expedient to emigrate. ${ }^{30}$

The final irony is that his solution for a controlled urban design would become, in basic terms, the accepted practice in the Soviet period. Before the revolution the neoclassical revival, despite a series of impressive and serviceable buildings, proved no more capable than the style moderne in devising a coherent theoretical system that would have guided architecture to a proper union of technology and design, cognizant of its responsibility to the age and to societal needs. After 1917 the appeal of the neoclassical revival on aesthetic and, to a certain extent, ideological grounds proved easily transferable to the heroic enthusiasm of the early period of Soviet power, when architects such as Fomin, Belogrud, and Shchuko produced numerous designs for public buildings in the so-called «Red Doric» or «proletarian classical» manner.

Nonetheless, the fact that almost every architect of prominence during the first two decades of Soviet architecture had built or designed in some variant of neoclassicism before the revolution is not, however, sufficient reason to assume that Soviet modernism, and Constructivism in particular, were essentially derived from a rationalist interpretation of the neoclassical revival. ${ }^{31}$ The protean nature of classicism as a critical term and as an architectural phenomenon demands a reasoned definition of its often contradictory impulses. When the neoclassical and Renaissance models were once again revived in the 1930s, often by cultured and knowledgeable architects, it was in service to a monumental deformation of humanist principles, as well as in response to what was decried as soulless modernism. Russian neoclassicism in this century, both before the revolution and, mutatis mutandis, in the 1930s, has been supported by ideologies opposed to modern styles (functional or decorative) in the name of a unified social and aesthetic vision. Yet classicism, then as now, is capable of reinterpretation and revival in ways that transcend the ideological claims of its most ardent proponents.

\footnotetext{
Among the many Russian publications that examine the style moderne, two of the most authoritative and comprehensive are: E. A. Borisova and T. P. Kazhdan, Russkaia arkhitektura kontsa XIX-nachala XX veka (Moscow: Nauka, 1971); and E. I. Kirichenko, Russkaia arkhitektura 1830-1910-kh godov (Moscow: Iskusstvo, 1978). In English the standard work is William C. Brumfield, The Origins of Modernism in Russian Architecture (Berkeley: University of California Press, 1991), A Russian version of the present article appeared in "Antimodernizm $\mathrm{i}$ vozrozhdenie klassitsizma v russkoi arkhitekture. 1906-1916 gg." In Predprinimatel'stvo i gorodskaia kul'tura $v$ Rossii. 1861-1914. Edited by William C. Brumfield, Boris V. Anan'ich, and Yuri A. Petrov (Moscow: Tri kvadrata, 2002), pp. 140-63.

2 A survey of Moscow's neoclassical revival architecture is contained in my chapter «Architectural Design in Moscow, 1890-1917: Innovation and Retrospection,» in William C. Brumfield, ed., Reshaping Russian Architecture: Western technology, utopian dreams (New York: Cambridge University Press, 1990), pp. 96-106.

3 This aspect of Fomin's early career is examined in V. G. Lisovskii, I. A. Fomin, (Leningrad: Lenizdat, 1979), pp. 10-11. Fomin's designs for houses in both the modern and neoclassical styles appeared in Ezhegodnik Obshchestva ArkhitektorovKhudozhnikov (Annual of the Society of Architect-Artists), no. 1 (1906), pp. 116-119. His work in subsequent issues of the architectural annual was devoted to variations on the classical theme.

$4 \quad$ Aleksandr Benois, «Zhivopisnyi Peterburg,» Mir iskusstva, 1902, no. 1: 1-5.
} 
5 The response to Benois on the part of architectural critics who supported the style moderne was predictably negative. See Brumfield, Origins of Modernism, p. 51.

Aleksandr Benois, «Krasota Peterburga,» Mir iskusstva, 1902, no. 8: 138-42.

Ivan Fomin, «Moskovskii klassitsizm,» Mir iskusstva, 1904, no. 7: 187.

Ivan Fomin, «Istoricheskaia vystavka arkhitektury v S.-Peterburge,» Starye gody, July-September, 1908, p. 178.

See Lisovskii, 53-68.

10 Lidval's work in both the style moderne and the neoclassical revival is summarized in V. G. Lisovskii, «Master Peterburgskogo moderna,» Stroitel'stvo i arkhitektura Leningrada, 1980, no. 1: 34-38.

11 Iurii Rokh, «Novoe stroitel'stvo v S.-Peterburge» (New Construction in St. Petersburg), Apollon, 1909, No. 1: 17. Lukomskii wrote extensively on architecture under the above pseudonym as well as his own name in Apollon. Lukomskii acknowledged authorship of the Rokh articles (in the first three issues of Apollon for 1909) in a footnote at the conclusion of his article «Novyi Peterburg,» Apollon, 1913, no. 2: 38.

12 For a survey of the career of Peretiatkovich, see his obituary by G. Kosmachevskii in Zodchii, 1916, no. 23: 219-20; and B. M. Kirikov, «Mar'ian Mar'ianovich Peretiatkovich,» Stroitel'stvo i arkhitektura Leningrada, 1973, no. 1: 30-31.

13 After the revolution Lialevich (1876-1944) returned to Warsaw, where he pursued an active architectural career. He died during the Warsaw Uprising. See B. M. Kirikov, «V rusle neoklassiki» (In the Direction of the Neoclassical), Stroitel'stvo i arkhitektura Leningrada, 1977, No. 6: 40-43.

14 Marian Lialevich, «Eshche o stile,» Zodchii, 1908, No. 15: 134.

15 The information on the New Petersburg project is contained in a technical report by the noted Petersburg civil engineer Aleksandr Montag, «Izmenenie plana ostrova Golodaia,» Zodchii, 1915, no. 49: 510; and from Georgii Lukomskii, «O postroike Novogo Peterburga,» Zodchii, 1912, no. 52: 519-21.

16 Lukomskii, «O postroike Novogo Peterburga,» pp. 520-21.

17 A number of Shchuko's sketches appeared in Ezhegodnik Obshchestva arkhitektorov-khudozhnikov, no. 2 (1907), pp. 142-45, as well as in other issues of this annual. Although Shchuko's Italian exhibition pavilions did not have a strong impact on his domestic work, they were among the most finely conceived of his neoclassical revival projects. The standard monograph on Shchuko is Tatiana Slavina, Vladimir Shchuko, (Leningrad: Lenizdat, 1978).

18 Lukomskii, «Neo-klasitsizm v arkhitekture Peterburga,» Apollon, 1914, no. 5: 10.

19 See Lukomskii, «Novyi Peterburg (Mysli o sovremennom stroitel'stve),» Apollon, 1913, no. 2: 25.

20 Lukomskii, «Arkhitekturnye vkusy sovremennosti,» Trudy IV S»ezda russkikh zodchikh (Petersburg, 1911), p. 28. A similar attack against «excessive» individualism appeared in Lukomskii's «Novyi Peterburg,» p. 9.

21 «Novyi Peterburg,» p. 22.

22 V. Machinskii, «Arkhitekturnye zametki,» Zodchii, 1914, no. 25: 297.

23 Ibid., 300.

24 Oskar Munts, «Parfenon ili Sv. Sofiia? K sporu o klassitsizme v arkhitekture,» Arkhitekturno-khudozhestvennyi ezhenedel'nik, 1916, no. 2: 19-22. The article by Benois, which appeared during November and December in the newspaper Rech' (Speech), took as its point of departure the neoclassical, retrospective trend in a recent show of student projects at the Academy of Arts.

25 A number of Munts's projects were published in Ezhegodnik Obshchestva arkhitektorov-khudozhnikov, no. 2 (1907), no. 4 (1909), no. 6 (1911), and no. 8 (1913). The 1912 volume contained a design for the main Moscow post office, which he co-designed with the engineer L. L. Novikov. The final design of the post office was modified by the Vesnin brothers. After the revolution Munts participated in the design of one of the first major industrial projects in the Soviet Union (the Volkhov GES, or hydroelectric station); and in subsequent years he continued to support the concept of rational design - to the extent that conditions permitted during the $1930 \mathrm{~s}$ - in both his architectural work and in his teaching at the Academy of Arts.

26 «Parfenon ili Sv. Sofiia?,» 22.

27 «Za arkhitekturu,» Arkhitekturno-khudozhestvennyi ezhenedel'nik, 1916, no. 9: 116. The polemic continued in subsequent issues during 1916, with replies from both Munts and Duodecim.

28 «Novyi Peterburg,» 10.

29 Sovremennyi Petrograd: Ocherk istorii vozniknoveniia i razvitiia klassicheskogo stroitel'stva, (Petrograd: Svobodnoe Iskusstvo, n. d.), 30. Subtitled «A Sketch of the history of the appearance and development of neoclassical construction,» the volume represents a compendium of Lukomskii's major writings on the neoclassical revival - including the 1913 and 1914 issues of Apollon - with an expanded preface, in which the above quotation appears.

30 Lukomskii (1884-1954), a descendant of Ukrainian nobility, left Russia by way of Kiev, where he participated in a survey of the city's medieval churches during 1918. After the withdrawal of German troops from the Ukraine at the end of the First World War, Lukomskii emigrated to France and resumed a prolific career as a writer, publishing frequently in French and English on European as well as Russian art. His lasting affection for the architecture of Italy and its classical values is reflected in his books on Venice, Rome, and the work of Vignola.

31 For further discussion of the complex relation between modern classicism in Russia and the rationalist approach to design, both before and after the revolution, see Selim Khan-Magomedov, Aleksandr Vesnin and Russian Constructivism (New York: Rizzoli, 1986), pp. 15, 34. The early Soviet fascination with «proletarian classicism»-whose romanticism reminds of architecture folowing the French revolution - is well illustrated in T. Suzdaleva, «Otkrytie naslediia revoliutsionnogo romantizma,» Arkhitektura SSSR, 1989, no. 2: 98-105. 


\title{
Возрождение классицизма \\ в архитектуре Санкт-Петербурга (Петрограда): \\ полемика и практика
}

\author{
У.К. Брумфильд \\ Университет Тулейн \\ Новый Орлеан, Луизиана, США
}

\begin{abstract}
После 1905 года реакция на модернистское движение в архитектуре появилась в работах архитекторов и критиков, которые поддерживали возрождение классицизма в русской архитектуре. Несмотря на то что новый классицизм предполагал применение технологических и дизайнерских инноваций в рамках установленной архитектурной системы, он также широко интерпретировался как отказ от неустойчивых ценностей индивидуализма и буржуазного этоса. Неоклассицистическая архитектура стала последней надеждой на примирение современной архитектуры с культурными ценностями, унаследованными от идеализации русского имперского величия. Тем не менее возрождение неоклассицизма в конечном счете проявляется в таком же отсутствии эстетического единства и теоретического направления, как и стиль модерн, таким образом вызывая у некоторых критиков и архитекторов сомнения относительно социального порядка, в рамках которого архитектура функционировала в течение десятилетий до революиии 1917 года. Эта дискуссия будет иметь долгосрочные последствия для советской архитектуры.

Ключевые слова: архитектура Петербурга, неоклассицизм, журнал «Старые Годы», журнал «Аполлон", стиль модерн, Венский сецессион, Оскар Муни, Федор Лидваль, Иван Фомин, Карл Росси, Владимир Щуко, Мариан Лялевич, Мариан Перетяткович, Георгий Лукомский, доходные дома, банки.
\end{abstract}

Научная специальность: 17.00.00-искусствоведение. 